\title{
Assessment of Socio-, Ecological and Economic Consequences of the Virtual Reality Eco-Tours Advancing*
}

\author{
Oleksit S. Goncharenko ${ }^{i}$, Stanislav O. Nikolayevii, \\ Marita S. Mrslovskaiii, VikTorita V. Pogodinaiv
}

According to many experts, humanity is on the verge of transformational changes, which are characterized not only by changes in the way of management, but also by changes in the philosophy of human existence. This situation is especially noticeable during crises on a global scale. One such demonstration was the global socio-economic crisis caused by the coronavirus pandemic. It can already be argued that some areas of the information technology industry are experiencing an extremely rapid pace of development, including virtual reality technology. This is especially true against the background of information that one of the negative consequences of the pandemic is an increase in cases of psychological tension in society as a whole and in individuals due to limited physical movement of people.

Therefore, the aim of this article was to study the prospects of implementing virtual reality technologies in the tourism business environment based on the identification and justification of possible positive and negative socio-environmental and economic results due to the development of this type of business at the regional level. The idea is to use virtual reality technologies to create a commercial product - "green" tourist tours in Sumy region (Ukraine), the essence of which is to enable tourists from anywhere in the world to virtually visit certain natural and landscape areas of Sumy region. The emphasis is not only on visiting historical architectural monuments, museums, but also on using the recreational potential of natural objects. For example, kayaking on the river Psel, hiking in Spadschansky forests, fishing on the Blue Lakes in Sumy, hunting animals, picking mushrooms, sports tours: running, skiing in the woods near the village. Turners.

Thus, the creation of eco-tours of virtual reality can be considered appropriate, because for both internal and external stakeholders, this type of activity is more positive than negative: for employees, the creative component of labor grows, the preconditions are created to increase wages; for consumers, the risks during the trip are reduced, the associated costs disappear, there are more options and opportunities for development; for the region, this type of activity guarantees environmental friendliness and greater interest due to the virtual reality tour in the area.

Keywords: virtual reality, socio-ecological-economic result, tourist business.

Abbreviation:

$\mathrm{VR}$ - virtual reality.

УДК: 338.48:004.946

JEL Codes: Z30, Z32

${ }^{i}$ Oleksii S. Goncharenko, C.Sc. (Economics), Senior Lecturer of the Department of Economics, Entrepreneurship and Business Administration, Sumy State University;

ii Stanislav O. Nikolayev, Student, Oleg Balatskyi Academic and Research Institute of Finance, Economics and Management, Sumy State University;

iii Mariia S. Myslovska, Sole Trader;

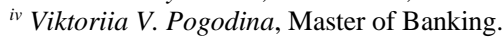

${ }^{*}$ This research was prepared as a part of the scientific project "Modeling the Transfer of Eco-Innovations in the Enterprise-Region-State System: Impact on Ukraine's Economic Growth and Security" (No. 0119U100364).

(C) O. S. Goncharenko, S. O. Nikolayev, M. S. Myslovska, V. V. Pogodina, 2020.

https://doi.org/10.21272/mer.2020.88.04 
Oleksii S. Goncharenko, Stanislav O. Nikolayev, Mariia S. Myslovska, Viktiriia V. Pogodina. Assessment of Socio-, Ecological and Economic Consequences of the Virtual Reality Eco-Tours Advancing

Introduction. According to many experts, humanity is on the verge of transformational changes, which are characterized not only by changes in the way of management, but also by changes in the philosophy of human existence. This situation is especially noticeable during crises on a global scale. One such demonstration was the global socio-economic crisis caused by the coronavirus pandemic. Its feature was the extremely rapid rate of spread, which did not allow society to adapt or find a way to counteract in this crisis situation. This will be the field for future research. However, it can now be argued that an effective technical tool, along with organizational and administrative measures, have been information technology, which has allowed not only to curb the spread of the virus, but also to mitigate the possible consequences.

Analysis of recent research and publications. Given the innovativeness of the category of virtual reality, especially in the economic sphere, the issue of its introduction into the tourism business environment is devoted to the work of a few scientists. Thus, among the main domestic we can single out a few, in particular Dychkovsky S., who in his work considers the use of augmented reality to meet the needs of consumers in order to improve the quality of service. Also, Vysotska V. explores virtual reality technologies as a tool to increase the efficiency of the tourism business at the pre-sale stage, ie at the stage of pre-selection of future travel, as a visualization of customer locations. In his works Bozhko L. analyzed people's desire for virtual life, revealed the importance of the virtual museum as an integrative cultural form, gave examples of virtual worlds online [10, 11, 12].

In his work, Daniel Guttenteg considers virtual reality as a software product in tourism. There are 6 areas in tourism in which virtual reality can be especially useful: planning and management, marketing, entertainment, education, accessibility and preservation of heritage. Adam Wagler conducted research on the emotional state of a person traveling. The user made a two-dimensional tour, a 360-degree immersive tour, or physical - went to the place and walked through the territory. It turned out that the lowest rates in the first type of tour, in all respects. As for 2 and 3, the indicators did not differ in all parameters. This suggests that virtual tourism can be a strong analogue of the real experience. The work of authors such as Myun Ja Kim, Chong Ki Lee, and Timothy Jung explored cognitive and affective responses as important mediators in predicting attendance and attendance. As a result of research, it was found that the cognitive reaction had a greater impact than the affective reaction to the intention to visit the destination in the VR. This study sheds light on why potential tourists visit the destinations shown in the VR [18, 19, 20].

Also, it can already be argued that some areas of the information technology industry are experiencing an extremely rapid pace of development. These include: GPS positioning, tracking the location of people, analyzing large data sets of geopositioning objects, globalization of video surveillance, eye identification system, online doctor consultations, automation of disinfection technologies, online training, virtual reality, etc.

It should be noted that one of the negative consequences of the pandemic is an increase in cases of psychological tension in society as a whole and in individuals, due to limited physical movement of people.

From an online survey of more than 7.000 respondents - residents of China, it became known that in the midst of the epidemic due to restrictions on movement and long-term confinement, there were signs of generalized anxiety disorder in $35.1 \%$, depression - in $20.1 \%$, sleep disorders - in $18.2 \%$. Anxiety and depressive disorders were mostly young people in China, and the risk of sleep disorders was more common among physicians [8]. Also, a screening study using the SCL-90 questionnaire showed that $70 \%$ of respondents had moderate and significantly increased rates of mental distress, as well as symptoms such as obsession, interpersonal sensitivity, anxiety and psychoticism (extraordinary mental experience) [9]. 
One of the tools to solve such problems in the "precoronavirus times" was tourism. However, as already mentioned, due to the restriction of movement of people around the world, this tool was not relevant. However, in the search for a solution to this problem, a possible solution is to use virtual reality technologies to satisfy tourist desires.

According to some authors $[11,12]$, virtual reality, which is moving from the entertainment industry to the plane of education, business and cultural development, can fill the vacuum of psychological tension created by the above crisis. Therefore, we believe that the development of business models aimed at improving socio-psychological problems is extremely relevant in today's realities. Moreover, the introduction of virtual reality can also have positive environmental and economic consequences.

Thus, the purpose of this article is to study the prospects of implementing virtual reality technologies in the tourism business environment based on the identification and justification of possible positive and negative socio-environmental and economic results due to the development of this type of business at the regional level.

As you can see, the study of virtual reality is quite limited to its main manifestations, are fragmentary in nature and so on. Nevertheless, we consider it necessary to develop virtual reality technologies as a separate business product in the field of green tourism, which will bring us closer to solving socio-environmental and economic problems.

The idea is to use virtual reality technologies to create a commercial product - "green" tourist tours in Sumy region (Ukraine). The essence of which is to provide customers from all over the world the opportunity to virtually visit certain natural and landscape areas of Sumy region. The emphasis is not only on visiting historical monuments, museums, but also on the use of recreational potential of natural objects. For example, kayaking on the river Psel, hiking in the Spadschansky forests, fishing on the Blue Lakes in Sumy, hunting animals, picking mushrooms, sports tours: running, skiing in the woods near the Tokari village.

Research results. First of all, let's define the main categories of research. Yes, reality itself, by omitting philosophical interpretations, can be true (really existing) and artificial. Artificial, in turn, can also take different forms, the main of which are shown in Fig. 1.

Virtual reality is a subspecies of augmented reality. Augmented reality, in turn, is a modification of the actual existing environment, through the introduction of certain technologies that at some stage give artificially created sensations to certain organs of information perception. A person understands that he is where he is, but can see, hear, feel things that are integrated into real reality.

Virtual reality (VR) is an artificially created world with the help of computer technology, which a person can comprehend through the senses such as sight, hearing, touch. VR mimics both influences and reactions to influences. Each virtual reality is a special software that follows a certain scenario and plays certain situations according to real time, in order to maximize the blurring of the framework between artificial and real worlds [5].

Mixed reality is a hybrid reality that is a fusion of real and virtual worlds to create new environments and visualizations where physical and digital objects coexist and interact in real time. Mixed reality occurs not only in the physical or virtual world, but is a mixture of the reality of our world and virtual reality [5].

Modulated reality - covers all types of realities created by information technology [5].

It is estimated that $80 \%$ of information a person receives through sight. Therefore, the developers of BP systems pay great attention to the devices that provide image formation. As a rule, they are supplemented by stereo imaging devices, work on tactile effects and even simulation of odors [5]. 
Oleksii S. Goncharenko, Stanislav O. Nikolayev, Mariia S. Myslovska, Viktiriia V. Pogodina. Assessment of Socio-, Ecological and Economic Consequences of the Virtual Reality Eco-Tours Advancing

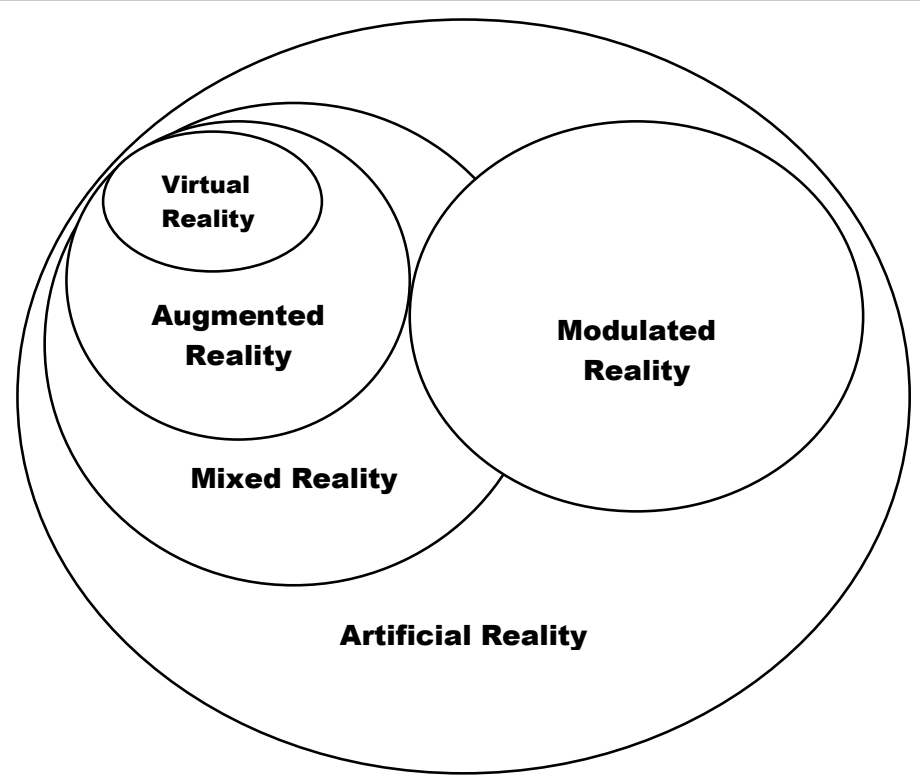

Figure 1. Types of artificial "reality" [4]

From the technical point of view, in order to immerse yourself in virtual reality, special glasses are used, which are called - virtual reality glasses. For full-fledged interaction with virtual reality also use 3D-controllers (manipulators that allow you to work in three-dimensional space). Also, as an additional tool for immersion in VR using virtual reality rooms, which represent a specially equipped space, where the computer-generated image is transmitted to its walls through displays or projectors.

As already mentioned, the VR is now beginning to be actively used in many spheres of public life. We can distinguish the following [7]:

- In training - used in training doctors, training to manage various technical means (cars, planes, etc.);

- In science - used to build complex structures of different levels (molecular, atomic); in medicine VR provides remote and more accurate control tools;

- In design - construction and editing of three-dimensional models of mechanisms, constructions, etc.; simulation and research of various effects on them;

- In the entertainment industry - concerts, games, etc.;

- In the military sphere - used to create artificial scenes of armed conflicts and staff training; training on special simulators for pilots; imitation of demining for sappers, etc.

Given the innovative technologies of VR, the creation and implementation of "green" tourist tours as a business product carries certain risks for owners. The main ones are the following:

- given the possible unavailability of technical equipment for the general public, as a result of insufficient sales and low gross profit and as a result the project may have too long a payback period, which may lead to its loss;

- insufficient number of qualified personnel to create and support VR products;

- lack of support from public authorities and local governments, etc. 
Despite certain risks, there are already obvious positive environmental effects from the use of explosives. In the context of a pandemic and global quarantine, the VR can "replace" air travel, hotel stays, museum visits, that is, anything that provided travelers with the effect of immersion in a particular area.

Experts predict that as a result of declining economic and industrial activity in 2020, for the first time since the financial crisis of 2008-2009, there will be a reduction in all global emissions and pollution [14]. In 2008, air emissions decreased by $50 \%$, but a year later the figures returned to the previous figures and even exceeded this figure by $5 \%$ than before the crisis [14]. The leader in the amount of pollutant emissions in the world is China [14]. The consequence of measures taken to contain the coronavirus was to reduce the production of key industries by 15-40\%. As a result, carbon emissions have been reduced by $25 \%$ per month, according to a study by Carbon Brief. This applies not only to China but also to other countries, including Europe, especially Italy [14].

According to some scientists [14], short-term eco-victories as a result of a pandemic can have negative consequences after its decline, as consumption and associated emissions can rise sharply. Although emissions of gases and pollutants have decreased, the demand for disposable personal hygiene items has increased. In many issues we will have to look for new solutions to already solved problems.

In addition to the cost component for making management decisions to implement a business project, it is important to adequately assess the possible results that the owner or stakeholders can get. For a more systematic analysis of this issue, we divide it into two elements. First of all, consider the range of all possible recipients who perceive the results of creating a business product of eco-tours of the VR in Sumy region. Note that the determining factor in the formation of the circle of recipients is the understanding of different levels of influence on them of the results of the business. In addition to the actual internal or internal results, you must take into account the external results or external.

Considering the system of recipients, it should be noted that they are all closely interconnected and interdependent. Therefore, depending on the level of perception of the results, we can identify the following recipients:

- internal, which can include the owner or group of owners and consumers or users of ecotours of the VR;

- external, which includes the community of the city or region and public authorities and local governments.

Obviously, the group of internal recipients is characterized by the perception or retention of direct economic benefits from the sale of eco-tours of VR in the form of income and profits or possible losses.

Less obvious, but no less important are external recipients, which are characterized by obtaining more social and environmental effects and indirectly economic results. It should also be noted that these groups of recipients also differ in the time lag of perception of these results. Thus, internal recipients perceive the results of this business without time delays, while external recipients perceive the results usually after some time. For example, the effects of improving the environment or attracting investment to the region occur over time.

We consider the logical continuation of the analysis to separate and systematize the actual results from the creation and implementation of eco-tours of the VR.

In the classical literature of the economics of nature management $[15,16,17]$ it is accepted to consider the results of management in three sections: socio-economic, ecological-economic and actually economic. Note that by nature all three results are varieties of economic result. 
Oleksii S. Goncharenko, Stanislav O. Nikolayev, Mariia S. Myslovska, Viktiriia V. Pogodina. Assessment of Socio-, Ecological and Economic Consequences of the Virtual Reality Eco-Tours Advancing

However, we consider it expedient to consider them in this way, in order to highlight their most important characteristics and opportunities for further effective management. Also, in order to provide the most complete information support for the decision-making process, we consider it necessary to investigate the emergence of possible negative business results for the creation and sale of eco-tours of the VR. The relationships and dependencies of the above groups of recipients with the specification of the results obtained from the creation and sale of eco-tours of VR are shown in Fig. 2.

In order to effectively manage the business, it is proposed to consider possible positive and negative results at different stages of the creation and use of eco-tours of the VR (Table 1).

Table 1

Possible positive and negative results / effects from the creation and sale of eco-tours of the VR in Sumy region

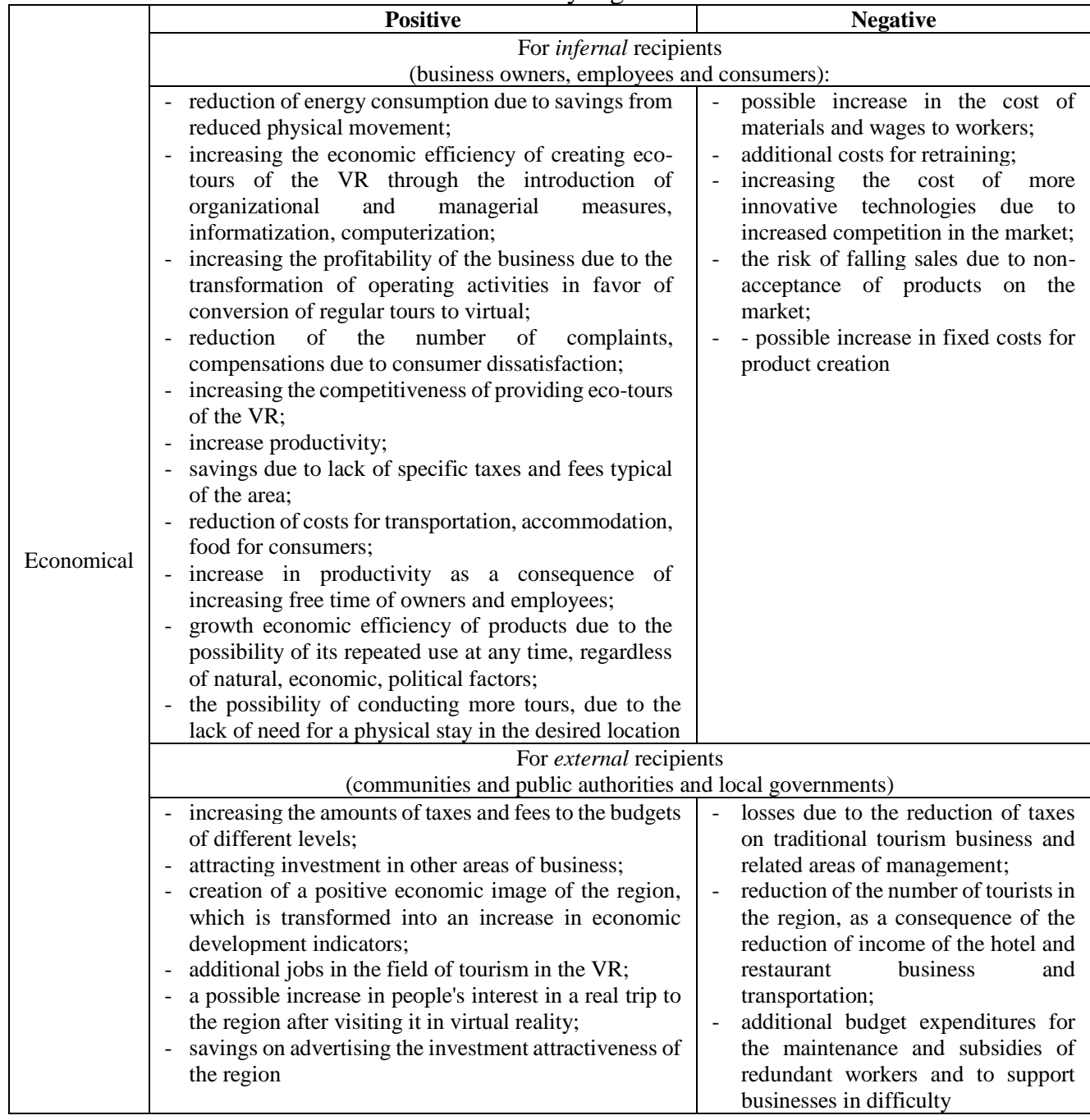




\begin{tabular}{|c|c|c|}
\hline \multirow{4}{*}{$\begin{array}{l}\text { Eco- } \\
\text { economical }\end{array}$} & \multicolumn{2}{|c|}{$\begin{array}{l}\text { For infernal recipients } \\
\text { (business owners, employees and consumers): }\end{array}$} \\
\hline & $\begin{array}{l}\text { - averted economic losses from the reduction of energy } \\
\text { use for physical movements at the stage of using VR } \\
\text { eco-tours; } \\
\text { - economic losses are prevented from reducing waste } \\
\text { reduction; } \\
\text { - increasing the value of the firm in the market due to the } \\
\text { strengthening of its "green" image; } \\
\text { - reduction of cases of specific diseases of employees and } \\
\text { / or owners; } \\
\text { - reduction of costs for hospital workers due to the } \\
\text { reduction of occupational injuries, occupational } \\
\text { diseases }\end{array}$ & $\begin{array}{l}\text { - additional economic losses from the } \\
\text { growth of energy consumption at the } \\
\text { stage of creating eco-tours of the VR; } \\
\text { - increase in losses from the increase in } \\
\text { morbidity from specific activities at } \\
\text { the stage of creation and use of eco- } \\
\text { tours of BP (from additional } \\
\text { electromagnetic load, additional load } \\
\text { on the senses of employees and } \\
\text { consumers) }\end{array}$ \\
\hline & \multicolumn{2}{|c|}{$\begin{array}{l}\text { For external recipients } \\
\text { (communities and public authorities and local governments) }\end{array}$} \\
\hline & $\begin{array}{l}\text { reduction of economic losses from the physical presence } \\
\text { of people in real places of eco-tours }\end{array}$ & $\begin{array}{l}\text { economic losses from the increase of the } \\
\text { material trace of innovative equipment } \\
\text { and technologies used in the creation and } \\
\text { use of eco-tours of the VR }\end{array}$ \\
\hline \multirow{4}{*}{$\begin{array}{l}\text { Socio- } \\
\text { economical }\end{array}$} & \multicolumn{2}{|c|}{$\begin{array}{c}\text { For infernal recipients } \\
\text { (business owners, employees and consumers): }\end{array}$} \\
\hline & $\begin{array}{l}\text { - increasing employee satisfaction from increasing the } \\
\text { creative component in the work; } \\
\text { - reduction of personal medical expenses of employees; } \\
\text { - reducing the number of accidents; } \\
\text { - improving the psycho-emotional state of employees; } \\
\text { - the ability to visit inaccessible areas at any time and } \\
\text { time of year for consumers; } \\
\text { - improving the psycho-emotional state of consumers, } \\
\text { especially in a period when real travel is impossible; } \\
\text { - increase the level of safety during the trip; } \\
\text { - reduction of fatigue during travel }\end{array}$ & $\begin{array}{l}\text { - possible job cuts and social tensions } \\
\text { as a result; } \\
\text { - possible discrepancy with the real } \\
\text { situation at the time of the tour with } \\
\text { real time, due to the irrelevance of the } \\
\text { program }\end{array}$ \\
\hline & \multicolumn{2}{|c|}{$\begin{array}{c}\text { For external recipients } \\
\text { (communities and public authorities and local governments) }\end{array}$} \\
\hline & $\begin{array}{l}\text { - providing guarantees to the community on the } \\
\text { environmental friendliness of the tour; } \\
\text { - the possibility of using the achievements of eco- } \\
\text { business to improve political positions for the } \\
\text { government; } \\
\text { - a sense of belonging to the solution of global social, } \\
\text { environmental, economic problems of communities and } \\
\text { authorities; } \\
\text { - increasing the cultural component of public life in the } \\
\text { region; } \\
\text { - activation of drivers of social development }\end{array}$ & $\begin{array}{l}\text { possible hostility and public } \\
\text { dissatisfaction with innovations, as a } \\
\text { consequence of boycotting and } \\
\text { blocking the development of this type } \\
\text { of business; } \\
\text { - others }\end{array}$ \\
\hline
\end{tabular}

Thus, the creation of eco-tours of virtual reality can be considered appropriate, because for both internal and external recipients, this type of activity is certainly more positive than negative. The creative component of work is growing for employees, and preconditions are being created for raising wages. For consumers, travel risks are reduced, associated costs are eliminated, and more options and opportunities appear. For the region, this type of activity guarantees environmental friendliness and greater interest due to the virtual reality tour in the area. 
Oleksii S. Goncharenko, Stanislav O. Nikolayev, Mariia S. Myslovska, Viktiriia V. Pogodina. Assessment of Socio-, Ecological and Economic Consequences of the Virtual Reality Eco-Tours Advancing

Conclusions and prospects for further research. The article considers the positive and negative results of the introduction of virtual tourism. This project is risky because it requires high priority costs, but the profits from its implementation can also be significant, given the novelty (innovation) of the concept, quality design and implementation. Given that this area is innovative, there are many areas for future research. For example, assessment of the effects of the introduction of virtual tours, assessment of the profitability of this product at the regional level, the competitiveness of the virtual tour along with the real one, and so on.

\section{References}

1. Woodford, C. (2020). Virtual reality. Explain that stuff, p. 1. Retrieved from https://www.explainthatstuff.com/virtualreality.html.

2. Top-10 naykrashchykh virtual'nykh ekskursiy v Ukrayini [Top 10 best virtual tours in Ukraine]. Web resource UNIAN - Veb-resurs Unian. Retrieved from https://www.unian.ua/tourism/lifehacking/10922969-top-10-naykrashchih-virtualnih-ekskursiy-vukrajini.html. [in Ukrainian].

3. Korotenko, O. (2020). Ne vykhodyachy z domu: virtual'ni ekskursiyi muzeyamy i ne til'ky [Without leaving home: virtual tours of museums and more]. Retrieved from https://bazilik.media/nevykhodiachy-z-domu-virtualni-ekskursii-muzeiamy-i-ne-tilky/. [in Ukrainian].

4. Dopovnena, virtual'na ta inshi real'nosti [Augmented, virtual and other realities]. Web resource "IT enterprise" - Veb-resurs "IT enterprise". Retrieved from https://www.it.ua/knowledgebase/technology-innovation/dopolnennaja-virtualnaja-i-prochie-realnosti [in Ukrainian].

5. Virtual'na real'nist' [VR] [Virtual Reality [VR]. Web resource "IT enterprise" - Veb-resurs "IT enterprise". Retrieved from https://www.it.ua/knowledge-base/technology-innovation/virtualnajarealnost-vr. [in Ukrainian].

6. Hogan, M. (2020). Where Can Virtual Concerts GAfter Travis Scott's Fortnite Extravaganza? Pitchfork, p. 1. Retrieved from https://pitchfork.com/thepitch/virtual-concerts-travis-scotts-fortnite100-gecs-minecraft/.

7. Virtual reality (2020). Wikipedia Web Resource, p. 1. Retrieved from https: //uk.wikipedia.org/wiki/ virtual reality.

8. Alekhine, A. N., Dubinina, E. (2020). Pandemyya: klynyko-psykholohycheskyy aspect [Pandemic: clinical and psychological aspect]. Arterial hypertension - Arteryal'naya hypertenzyya. p. 1-5. Retrieved from https://cyberleninka.ru/article/n/pandemiya-kliniko-psihologicheskiy-aspekt. [in Russian].

9. Dychkovsky, S. (2019). Inkorporatsiya virtual'nykh praktyk v systemu virtual'noho turyzmu. [Incorporation of virtual practices into the system of virtual tourism]. "Culturology" "Kul'turolohiya"]. $\quad$ p. $\quad 1-9 . \quad$ Retrieved from http://elib.nakkkim.edu.ua/xmlui/bitstream/handle/123456789/730/Incorporation\%20of\%20visual\%2 0practices\%20into\%20a\%20virtual\%20tourism\%20system.pdf?sequence=1\&isAllowed=y. $\quad$ [in Ukrainian].

10. Vysotska, V. (2018). Innovatsiyi v turyzmi: virtual'na real'nist' [Innovations in tourism: virtual reality]. Proceedings of the XI All-Ukrainian Student Scientific and Technical Conference "Sustainable Urban Development" - Materialy KHI Vseukrayins'koyi student.s'koyi naukovo-tekhnichnoyi konferentsiyi «Stalyy rozvytok mist. p.64-66. Retrieved from: http://eprints.kname.edu.ua/49563/1/ilovepdf_com65-67.pdf [in Ukrainian].

11. Bozhko, L. (2015). Virtual'nyy turyzm: novi viyannya chasu [Virtual tourism: new trends of the time]. Publication "Culture of Ukraine" - Vydannya "Kul'tura Ukrayiny" p. 151-158 [in Ukrainian].

12. Dychkovsky, S. (2019). Kul'turnyy turyzm yak sfera realizatsiyi dozvillyevykh tekhnolohiy ta virtual'noho dosvidu [Cultural tourism as a sphere of realization of leisure technologies and virtual experience]. Herald $\quad$ V Visnyk. Retrieved http://journals.uran.ua/visnyknakkkim/article/view/191781 [in Ukrainian].

13. Kolesnichenko, A. (2020). Nachalo myrovoho kryzysa? Chto stoyt za obvalom rynka aktsyy, valyuty y nefty [The beginning of the global crisis? What is behind the collapse of the stock market, currency 
and oil]. Economic Truth - Vydannya "Ékonomycheskaya pravda". Retrieved from https: //www. althoughda.com.ua/rus/publications/2020/03/10/657889/ [in Ukrainian].

14. Melnik, L. G., Sotnik, I. N. (2011). Kontseptual'nye osnovy upravlenyya demateryalyzatsyey sotsyal'no-ékonomycheskykh system [Conceptual foundations of management of dematerialization of socio-economic systems]. Actual problems of development of social and economic systems: theory and practice. Sat. Articles of the III International Scientific and Practical Conference / ed. when. Minakova. Eagle: APLIT - Aktual'nye problemy razvytyya sotsyal'no-ékonomycheskykh system: teoryya y praktyka. Sb. statey III mezhdunarodnoy nauchno-praktycheskoy konferentsyy / red. kol.: Y.V. Mynakova. Orel: APLYT]. P. 62-70. [in Ukrainian].

15. Meadows, D., Randers, J. (2007). The limits of growth. 30 years later. Per. with English M.: ICC "Akademkniga", 342p.

16. Sotnyk, I. M. (2010) Upravlinnya resursozberezhennyam: sotsio-ekoloho-ekonomichni aspekty: monohrafiya [Management of resource conservation: socio-ecological and economic aspects: a monograph]. Sumy: SSU Publishing House - Sumy: Vyd-vo SumDU. 499 p. [in Ukrainian].

17. Guttentag, D. (2010). Virtual reality: Applications and implications for tourism. Tourism management, p. 637-651.

Retrieved from: https://www.sciencedirect.com/science/article/abs/pii/S0261517709001332.

18. Wagler, A., Hanus, M. (2018). Comparing Virtual Reality Tourism to Real-Life Experience: Effects of Presence and Engagement on Attitude and Enjoyment. Communication Research Reports, p. 456464. Retrieved from: https://www.tandfonline.com/doi/abs/10.1080/08824096.2018.1525350.

19. Myung Ja Kim, Choong-Ki Lee, Timothy Jung. (2018). Exploring consumer behavior in Virtual Reality tourism using an extended stimulus-organism-response model. Journal of travel research, p. 69-89. Retrieved from: https://journals.sagepub.com/doi/abs/10.1177/0047287518818915.

20. Goncharenko, O. S. (2015). Naukovo-metodychnyy pidkhid do otsinyuvannya rivnya ekolohichno spryamovanoyi dematerializatsiyi sotsial'no-ekonomichnykh system [Scientific and methodological approach to assessing the level of environmentally oriented dematerialization of socio-economic systems]. Mechanism of economic regulation - Mekhanizm rehulyuvannya ekonomiky. № 1. p. 127134 [in Ukrainian].

21. Goncharenko, O. S. (2014). Formuvannya modeli rynku povtornoho vykorystannya tovariv u konteksti dematerializatsiyi ekonomiky [Formation of the market model of reuse of goods in the context of dematerialization of the economy]. Economy: the realities of time - Ekonomika: realiyi chasu. № 6 (16). Pp. 188-192 [in Ukrainian].

22. Melnik, L. G., Chortok, Y. V., Goncharenko, A. S. (2013). Zabezpechennya staloho rozvytku rehionu na osnovi dematerializatsiyi diyal'nosti rehional'nykh lohistychnykh tsentriv [Ensuring sustainable development of the region based on dematerialization of regional logistics centers]. Bulletin of socioeconomic research - Visnyk sotsial'no-ekonomichnykh doslidzhen'. №2 (49). p. 174-179 [in Ukrainian].

Manuscript received 03 Marth 2020

Оценка социо-эколого-экономических результатов внедрения эко-туров виртуальной реальности

\section{АЛЕКСЕЙ СЕРГЕЕВИч ГОНЧАРЕНКо*,} СТАНИСЛАВ АЛЕКСАНДРОВИч НИКОЛАЕв ${ }^{* *}$ МАРИЯ СЕРГЕЕВНА МЫСЛОВСКАЯ ${ }^{* * *}$, ВиктоРИЯ ВикторОвНА ПогодинА ${ }^{* * * *}$

\footnotetext{
* кандидат экономических наук, старший преподаватель кафедры экономики, предпринимательства и бизнес-администрирования Сумского государственного университета, ул. Р.-Корсакова, 2, г. Сумы, 40007, Украина, тел.: 00-380-542-332223, е-mail: o.goncharenko@econ.sumdu.edu.ua
} 
Oleksii S. Goncharenko, Stanislav O. Nikolayev, Mariia S. Myslovska, Viktiriia V. Pogodina. Assessment of Socio-, Ecological and Economic Consequences of the Virtual Reality Eco-Tours Advancing

** студент Учебно-научного института финансов, экономики и менеджмента имени Олега Балачкого Сумского государственного университета, ул. Р.-Корсакова, 2, г. Сумы, 40007, Украина тел.: 00-380-95-7218725, e-mail: coldbulgakov@gmail.com

***: физическое лицо - предприниматель, ул. Герасима Кондратьева, 127/1, кв. 35, г. Сумы, 40021, Украина, тел.: 00-380-95-2381330, e-mail: myslovskam11@gmail.com

***** магистр банковского дела,

ул. Нижнесыроватская, 60, кв. 8, г. Сумы, 40007, Украина, тел.: 00-380-66-2718017, e-mail:pogod_ina@ukr.net

По мнению многих экспертов, человечество находится на грани трансформационных изменений, которые характеризуются изменениями не только в способе хозяйствования, но и изменениями в философии существования человека. Особенно такая ситуация становится заметной во время кризисных явлений планетарного масштаба. Одним из таких показательных явлений стал глобальный социально-экономический кризис, который был вызван пандемией коронавируса. Уже сейчас можно утверждать, что некоторые направления информационно-технической отрасли переживают чрезвычайно стремительные темпы развития, в том числе, и технологии виртуальной реальности. Это особенно актуально на фоне информации о том, что одним из негативных последствий пандемии является увеличение случаев психологической напряженности общества в целом и отдельных индивидов из-за ограничений физического передвижения людей.

Целью данной статьи стало исследование перспектив внедрения технологий виртуальной реальности в туристическую бизнес-среду на основе идентификации и обосновании возникновения возможных положительных и отрицательных социо-эколого-экономических результатов вследствие развития данного вида бизнеса на региональном уровне. Идея заключается в том, чтобы использовать технологии виртуальной реальности для создания коммерческого продукта «зеленых» туристических туров в Сумской области (Украина), суть которых заключается в предоставлении клиентам из любого уголка мира возможности виртуально посетить определенные природно-ландшафтные зоны Сумщины. При этом акцент делается не только на посещении исторических памятников архитектуры, музеев, но и на использование рекреационного потенциала именно природных объектов. Например, байдарочный сплав по р. Псел, пешие прогулки в Спадщанских лесах, рыбалка на Голубых озерах в г. Сумы, охота на животных, сбор грибов, спортивные туры: бег, катание на лыжах лесном массиве вблизи с. Токари.

Таким образом, создание эко-туров виртуальной реальности можно считать целесообразным, поскольку для интернальних и экстернальных стейкхолдеров этот вид деятельности является более положительным, чем отрицательным: для работников растет творческая составляющая труда, создаются предпосылки для повышения заработной платы; для потребителей уменьшаются риски во время путешествия, исчезают сопутствующие расходы, появляется больше вариантов и возможностей для развития; для региона этот вид деятельности гарантирует экологичность и большую заинтересованность в результате тура виртуальной реальности на местности.

Ключевые слова: виртуальная реальность, социо-эколого-экономический результат, туристический бизнес.

Mechanism of Economic Regulation, 2020, No 2, 48-60 ISSN 1726-8699 (print) 
О. С. Гончаренко, С. О. Ніколаєв, М. С. Мисловська, В. В. Погодіна.

Оцінка соціо-еколого-економічних результатів впровадження еко-турів віртуальної реальності

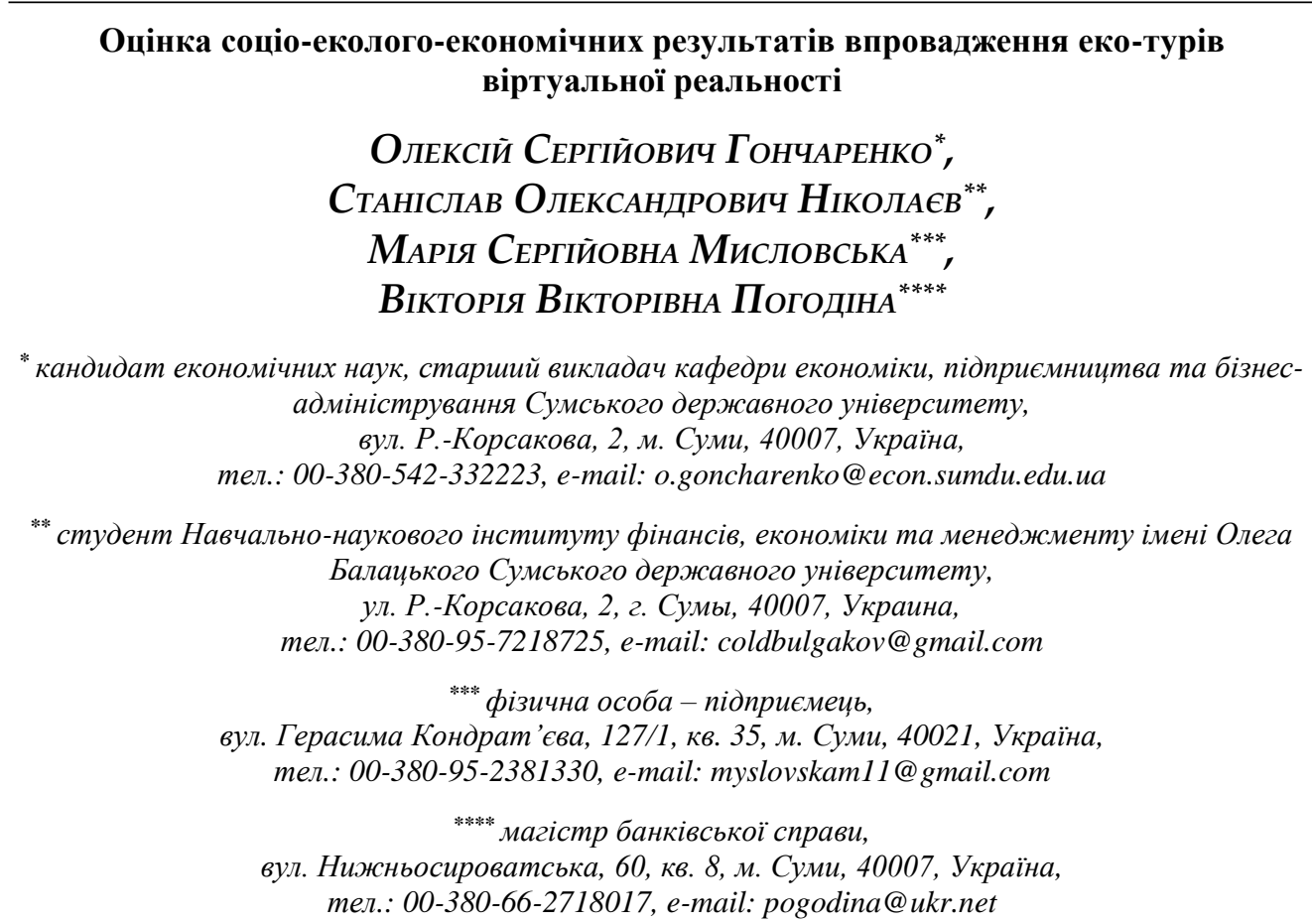

На думку багатьох експертів, людство знаходиться на межі трансформаційних змін, які характеризуються змінами не тільки в способі господарювання, а й змінами в філософії існування людини. Особливо така ситуація стає помітною під час кризових явищ планетарного масштабу. Одним з таких показових явищ стала глобальна соціально-економічна криза, яка була викликана пандемією коронавірусу. Вже зараз можна стверджувати, що деякі напрямки інформаційнотехнічної галузі переживають надзвичайно стрімкі темпи розвитку, в тому числі, і технології віртуальної реальності. Це особливо актуально на тлі інформації про те, що одним 3 негативних наслідків пандемії є збільшення випадків психологічної напруженості суспільства в цілому і окремих індивідів через обмеження фізичного пересування людей.

Метою даної статті стало дослідження перспектив впровадження технологій віртуальної реальності в туристичне бізнес-середовище на основі ідентифікації та обгрунтуванні виникнення можливих позитивних і негативних соціо-еколого-економічних результатів внаслідок розвитку даного виду бізнесу на регіональному рівні. Ідея полягає в тому, щоб використовувати технології віртуальної реальності для створення комерційного продукту - «зелених» туристичних турів в Сумській області (Україна), суть яких полягає в наданні клієнтам з будь-якого куточка світу можливості віртуально відвідати певні природно-ландшафтні зони Сумщини. При цьому акцент робиться не тільки на відвідуванні історичних пам'яток архітектури, музеїв, а й на використання рекреаційного потенціалу саме природних об'єктів. Наприклад, байдарковий сплав по р. Псел, піші прогулянки в Спадщанському лісах, рибалка на Блакитних озерах у Сумах, полювання на тварин, збір грибів, спортивні тури: біг, катання на лижах лісовому масиві поблизу с. Токарі.

Таким чином, створення еко-турів віртуальної реальності можна вважати доцільним, оскільки для інтернальних і екстернальних стейкхолдерів цей вид діяльності є більш позитивним, ніж негативним: для працівників зростає творча складова праці, створюються передумови для підвищення заробітної плати; для споживачів зменшуються ризики під час подорожі, зникають супутні витрати, з'являється більше варіантів і можливостей для розвитку; для регіону цей вид 
Oleksii S. Goncharenko, Stanislav O. Nikolayev, Mariia S. Myslovska, Viktiriia V. Pogodina. Assessment of Socio-, Ecological and Economic Consequences of the Virtual Reality Eco-Tours Advancing

діяльності гарантує екологічність і велику зацікавленість в результаті туру віртуальної реальності на місцевості.

Ключові слова: віртуальна реальність, соціо-еколого-економічний результат, туристичний бізнес.

JEL Codes: $\mathrm{Z} 30, \mathrm{Z} 32$

Figures: 1; Tables: 1; References: 22

Language of the article: English

Лimepamypa

1. Woodford, C. Virtual reality [Electronic resource] / C. Woodford // Explain that Stuff. - 2020. Accessed mode : https://www.explainthatstuff.com/virtualreality.html.

2. Топ-10 найкращих віртуальних екскурсій в Україні [Електронний ресурс] // Інформаційне агентство УНІАН. https://www.unian.ua/tourism/lifehacking/10922969-top-10-naykrashchih-virtualnih-ekskursiy-vukrajini.html.

3. Коротенко, O. Не виходячи з дому: віртуальні екскурсії музеями і не тільки [Електронний pecypc] // Bazilik. - 2020. - Режим доступу: https://bazilik.media/ne-vykhodiachy-z-domuvirtualni-ekskursii-muzeiamy-i-ne-tilky

4. Доповнена, віртуальна та інші реальності [Електронний ресурс] // IT-Enterprise. - Режим доступу : https://www.it.ua/knowledge-base/technology-innovation/dopolnennaja-virtualnaja-iprochie-realnosti.

5. Віртуальна реальність [VR] [Електронний ресурс] // IT-Enterprise. - Режим доступу: https://www.it.ua/knowledge-base/technology-innovation/virtualnaja-realnost-vr.

6. Hogan, M. Where Can Virtual Concerts Go After Travis Scott's Fortnite Extravaganza? [Electronic resource] / M. Hogan // Pitchfork. - 2020. - Accessed mode : https://pitchfork.com/thepitch/virtualconcerts-travis-scotts-fortnite-100-gecs-minecraft.

7. Віртуальна реальність [Електронний ресурс] // Вікіпедія. - 2020. - Режим доступу: https://uk.wikipedia.org/wiki/Віртуальна_реальність.

8. Алёхин, А. Н. Пандемия: клинико-психологический аспект [Электронный ресурс] / А. Н. Алёхин, Е. А. Дубинина // Артериальная гипертензия. - 2020. - № 3 (26) - С. 312-316. Режим доступа : https://cyberleninka.ru/article/n/pandemiya-kliniko-psihologicheskiy-aspekt.

9. Дичковський, C. I. Інкорпорація віртуальних практик в систему віртуального туризму [Електронний ресурс] / С. І. Дичковський // Культурологія. - 2019. - № 2. - С. 16-24. Режим доступу : $\quad$ http://elib.nakkkim.edu.ua/xmlui/bitstream/handle/123456789/730/ Incorporation \%20of\%20visual\%20practices\%20into\%20a\%20virtual\%20tourism\%20system.pdf?se quence $=1 \&$ is Allowed $=\mathrm{y}$.

10. Висоцька, В. Інновації в туризмі: віртуальна реальність [Електронний ресурс] / В. Висоцька // Матеріали XI Всеукраїнської студентської науково-технічної конференції «Сталий розвиток міст», (24-26 квітня 2018 р.). - Харків. - 2018. - С. 64-66. - Режим доступу : http://eprints.kname.edu.ua/49563/1/ilovepdf_com-65-67.pdf.

11. Божко, Л. Д. Віртуальний туризм: нові віяння часу [Електронний ресурс] / Л. Д. Божко // Культура України. Серія : Культурологія. - 2015. - Вип. 49. - С. 151-158. - Режим доступу : http://nbuv.gov.ua/UJRN/Kukl_2015_49_16.

12. Дичковський, C.I. Культурний туризм як сфера реалізації дозвіллєвих технологій та віртуального досвіду [Електронний ресурс] / С. І. Дичковський // Вісник Національної академії керівних кадрів культури і мистецтв. - 2019. - № 3. - С. 89-95. - Режим доступу: http://journals.uran.ua/visnyknakkkim/article/view/191781.

13. Колесниченко, А. Начало мирового кризиса? Что стоит за обвалом рынка акций, валюты и нефти [Электронный ресурс] / А. Колесниченко // Экономическая правда. - 2020. - Режим доступу : https://www.epravda.com.ua/rus/publications/2020/03/10/657889. 
О. С. Гончаренко, С. О. Ніколаєв, М. С. Мисловська, В. В. Погодіна.

Оцінка соціо-еколого-економічних результатів впровадження еко-турів віртуальної реальності

14. Мельник, Л. Г. К Концептуальные основы управления дематериализацией социальноэкономических систем [Электронный ресурс] / Л. Г. Мельник, И. Н. Сотник // Актуальные проблемы развития социально-экономических систем: теория и практика. Сборник статей III Международной научно-практической конференции (30 мая 2011 г.) ; ред. кол.: И. В. Минакова (отв. ред.) [и др.]. - Орел : АПЛИТ, 2011. - С. 62-70. - Режим доступу : http://essuir.sumdu.edu.ua/handle/123456789/29801.

15. Медоуз, Д. Пределы роста. 30 лет спустя / Д. Медоуз, Й. Рандерс, Д. Медоуз ; пер. с англ. - М. ИКЦ «Академкнига», 2007. - 342 с.

16. Сотник, I. М. Управління ресурсозбереженням: соціо-еколого-економічні аспекти: монографія / І. М. Сотник. - Суми : Вид-во СумДУ, 2010. - 499 с.

17. Guttentag, D. Virtual reality: Applications and implications for tourism [Electronic resource] / Daniel A. Guttentag // Tourism Management. - 2010. - Volume 31. - Issue 5. - P. 637-651. Accessed mode : https://www.sciencedirect.com/science/article/abs/pii/S0261517709001332.

18. Wagler, A. Comparing Virtual Reality Tourism to Real-Life Experience: Effects of Presence and Engagement on Attitude and Enjoyment [Electronic resource] / A. Wagler, Michael D. Hanus // Communication Research Reports. - 2018. - Volume 35. - Issue 5. - P. 456-464. - Accessed mode : https://www.tandfonline.com/doi/abs/10.1080/08824096.2018.1525350.

19. Kim, M. Ja. Exploring Consumer Behavior in Virtual Reality Tourism Using an Extended StimulusOrganism-Response Model [Electronic resource] / Myung Ja Kim, Choong-Ki Lee, Timothy Jung // Journal of travel research. - 2018. - Volume 59. - Issue 1 - P. 69-89. - Accessed mode : https://journals.sagepub.com/doi/abs/10.1177/0047287518818915.

20. Гончаренко, О. С. Науково-методичний підхід до оцінювання рівня екологічно спрямованої дематеріалізації соціально-економічних систем [Електронний ресурс] / О. С. Гончаренко // Механізм регулювання економіки. - 2015. - № 1. - С. 127-134. - Режим доступу: https://essuir.sumdu.edu.ua/handle/123456789/41857.

21. Гончаренко, О.С. Формування моделі ринку повторного використання товарів у контексті дематеріалізації економіки [Електронний ресурс] / О. С. Гончаренко // Економіка: реалії часу. -2014. - № 6 (16). - С. 188-192. - Режим доступу : http://nbuv.gov.ua/UJRN/econrch_2014_6_29.

22. Мельник, Л. Г. Забезпечення сталого розвитку регіону на основі дематеріалізації діяльності регіональних логістичних центрів [Електронний ресурс] / Л. Г. Мельник, Ю. В. Чорток, А. С. Гончаренко // Вісник соціально-економічних досліджень. - Ч. II. - №2 (49). - 2013. С. 174-179. - Режим доступу : http://essuir.sumdu.edu.ua/handle/123456789/69027. 